\title{
Nativization processes in L1 Esperanto
}

\author{
Benjamin K. Bergen \\ Linguistics Department, University of California, Berkeley
}

I would like to thank the organizers of the Infana Kongreseto, especially Jean-François Passarella, for allowing me consult with these very charming Native Esperantophones, as well as Aline Voldoire and Antoinette Guigues for convincing me, reticent as I was, that Esperanto was worthy of linguistic study. Finally, John McWhorter, James Matisoff, Dan Slobin, and two anonymous reviewers provided invaluable feedback on this work. All mistakes, omissions, and the like are mine. 
Address for correspondence: Benjamin Bergen, Department of Linguistics, 1203 Dwinelle Hall, UC Berkeley, Berkeley, California 94720, USA.

ABSTRACT

The artificial language Esperanto is spoken not only as a second language, by its proponents, but also as a native language by children of some of those proponents. The present study is a preliminary description of some characteristics of the Native Esperanto (NE) of eight speakers, ranging in age from six to fourteen years. As such, it is the first of its kind - previous works on NE are either theoretical treatises or individual case studies. We find, at least for the eight subjects studied, both bilingualism and nativization effects, differentiating native from non-native Esperanto speech. Among these effects are loss or modification of the accusative case, phonological reduction, attrition of the tense/aspect system, and pronominal cliticization. The theoretical ramifications are discussed, particularly with regard to universals of language acquisition and the effects of expressive requirements of language. 


\section{Nativization processes in L1 Esperanto}

INTRODUCTION

Esperanto is an artificial language, created by L. L. Zamenhof, at the end of the nineteenth century. Zamenhof, who was born in Bialystok (at the time in Lithuania) in 1859, was a polyglot, by all accounts able to speak fluent Polish, Yiddish, and Russian, in addition to having a good command of German, Hebrew, Latin, and French (Boulton 1960). His language, the result of 13 years of work, was published in 1887 and displays an immense lexical influence from Romance languages. By some estimates as many as $75 \%$ of Esperanto words are from Romance sources. Some researchers, such as Hockett (1958) even suggest it is typologically a Romance language, although this proposal is rejected by others, like Balbin (1987). There is also a distinct Slavic influence on Esperanto, as noted by Duc Goninaz (1974) as well as a Yiddish one, described by Piron (1984).

The particularly transparent etymology of the great majority of the language's lexemes and its simple syntax have positioned Esperanto as a candidate for an international language, and it has been the world's most-spoken artificial language for a century. Precise numbers for Esperantophones worldwide are elusive, with estimates ranging from 300,000 to 10,000,000 (Pei 1958; Forster 1982; Janton 1993). There are large numbers of Esperantophones in the former Soviet Union and Soviet Bloc and significant numbers elsewhere in Europe and in Eastern Asia, but fewer in the Americas and in Africa (Forster 1982).

Despite this relatively large linguistic 'community', however, there are only 350 or so documented cases of Esperanto taught to children as their L1 (Corsetti 1996). Corsetti observes that in these 
families, it is predominantly fathers who speak to their children in Esperanto; there is only a handful of documented cases of mothers doing so. Moreover, it is not the case that all Esperanto-speaking families have mixed-L1 couples, as might be suspected. Rather, the majority of families who speak Esperanto in the home consist of same-L1 couples who decide to raise their children with Esperanto as well as the local national language, or the maternal language of the parents. There are no documented cases of Esperanto as the sole language taught to a child for any extended period of time. Native Esperantophones are thus always bilingual.

The linguistic study of Native Esperanto (NE) has been extremely limited. There are, however, a few early case studies, the first in 1919, cited by Corsetti (1996), the second Butler (1921), which is an account of the linguistic development of the author's own children, with special reference to linguistic transfer between English and Esperanto. Additionally, a short case study of a child learning Esperanto as an L1 is found in Corsetti (1994). However, prior to the present paper, there have been no systematic or empirical multi-speaker surveys of NE, or the native use of any artificial language, for that matter.

The only non-partisan theoretical linguistic work on NE (as opposed to a discussion of its merits) is Versteegh (1993), an argument for considering the native acquisition of Esperanto in terms of pidginization and creolization theories. He suggests that in certain situations, the acquisition of Esperanto as a second language is homologous to pidginization, in that a communicative code is used without full regularity, and this code becomes the native language of the next generation. For example, if a couple with only Esperanto in common reproduces before being fully fluent in the language, their child would act as a creolizer, and one might expect to find the emergence of regularity in the child's language where regularity is limited in the parental input. However, he posits that Esperanto is not likely to undergo 
fundamental structural changes, because in actuality the parents of NE speakers typically learn the language by taking courses and using grammars, dictionaries, and other language learning tools not present in pidginization situations. This, he believes, affords them a degree of linguistic expertise not accessible to pidgin speakers.

Versteegh supports this argument on the basis of an analogy with Modern Hebrew. Modern Hebrew's first native speakers were indeed bilingual and they had varying degrees of exposure to L2 Hebrew. The developments that Modern Hebrew underwent when it became the native language of the children of non-native speakers were very minor, and did not include major structural changes. Versteegh thus argues that none might be expected in NE. ${ }^{1}$ However, no studies exist which could confirm or deny the claim that NE would closely resemble L2 Esperanto.

\section{METHOD}

Subjects

The present work responds to this lack of research on NE by presenting a preliminary survey of the natural speech of $8 \mathrm{NE}$ speakers, all children who participated in the Infana Kongreseto (Children's Congress) in Sommières, France, in August of 1998. These children had a variety of ADSTRATE languages and ranged in age from six to fourteen. Their adstrates (and ages) were: Hebrew (ages 10 and 13), Slovak (ages 9 and 11), French (age 6), Swiss German (age 9), Russian (age 14), and Croatian (age 11) $($ Mean = 10.4, S. D. = 2.5). All children were raised in households in which one parent addressed them primarily in Esperanto. 


\section{Procedure}

Interviews in Esperanto of around fifteen minutes each were recorded. During the interviews, the children were asked about themselves and engaged in conversation, and were also asked to narrate stories comprised of several sets of images depicting a child's activities through a day. These conversations were then transcribed by the investigator and analyzed for their similarites to and divergences from standard Esperanto.

A second body of data which was compared against the first was composed of L2 Esperanto (L2E). One part was an interview in Esperanto with the mother of the Francophone child, which was recorded and analyzed as above. The second was drawn from an analysis of the spontaneous L2E speech of two adult speakers by Sherwood (1982). These two elements constituted an independent corpus of spoken L2 Esperanto used as evidence for the current L2E norm.

The goal of the present study is twofold. First, we attempt to characterize NE for a range of particular children and suggest some possible observations for NE speakers in general from this sample. Also in the first section, we describe the extent to which NE differs from L2E 'Standard Esperanto' (SE). SE will be defined as prescribed Esperanto, as described in Kalocsay \& Waringhien (1985), the language's most thorough and frequently consulted grammar. Finally, we investigate some possible motivations for the differences between NE, SE, and L2E. We hypothesize that there might be influence from (1) the children's adstrate (i.e. the effects of bilingualism), (2) adstrate influence on the parent's Esperanto (learned as an L2), and (3) from pure nativization effects (c.f. Mühlhäuser 1980; Sankoff \& Laberge 1980; Versteegh 1993; Samarin 1994).

This study is limited in scope in two ways. First, eight children representing six adstrate languages clearly do not represent the world's languages. Of course, with only approximately $350 \mathrm{NE}$ 
speakers worldwide, this is a sizable sample. Second, data from only one parent is available, so we will not be able to determine in all cases the origin of certain SE - NE differences.

\section{RESULTS}

NE will be shown below to differ from SE and from L2E in the following ways: (2.1) NE uses no compound tenses nor aspectual affixes; (2.2) it undergoes a good deal of phonological reduction, especially in grammatical suffixes and other unstressed syllables; (2.3) its sentences are mostly SVO, but both verb and object (or complement) fronting do occur; (2.4) it uses the accusative in only approximately half of its 'appropriate' contexts; and (2.5) its stress is not always penultimate as in SE, but rather varies radically depending on the adstrate language of the NE speaker.

Tense/aspect. SE theoretically makes extensive use of compound verb + participle constructions to convey tense and aspect. The progressive is expressed by the verb esti 'to be' plus an active or passive present participial form, as shown in (1a) and (b) respectively:

(1a) Gi estas/estis/estos konstruanta

It $\{$ is/was/will be $\}$ constructing

(1b) Gi estas/estis/estos konstruata

It $\{$ is/was/will be $\}$ constructed 
The perfective in (2) is also formed with esti, this time followed by an active or passive past participle:

(2a) Gi estas/estis/estos konstruinta

It $\{$ has/had/will have $\}$ been constructing

(2b) Gi estas/estis/estos konstruita

It $\{$ has been/had been/will be being $\}$ constructed

The propsective is similarly formed with esti and a future participle:

(3a) Gi estas/estis/estos konstruonta

It $\{$ was/is/will be $\}$ to be constructing

(3b) Gi estas/estis/estos konstruota

It $\{$ has been/had been/will be $\}$ to be being constructed

Mastery of this complex system proves challenging for speakers of natural languages which do not express the full range of these concepts grammatically. For this reason alone, we see paradigm trimming in L2 Esperanto and expect it in NE. ${ }^{2}$

In the 30 minutes of L2 Esperanto (L2E) speech transcribed and analyzed by Sherwood (1982), there are nine forms with -ata (1), -inta (1), and -ita (7) suffixes (Table 1). Additionally, the French mother's speech only permitted one compound form, estis uzata 'was used'. However, in none of this L2E speech did any of the other participles occur. In sum, L2E retains certain compound verbal structures, principally those involving the past passive participle, but loses most others. 
< Insert Table 1 about here >

The obvious question to pose regards the status of these verbal forms in NE. Without equivocation, there is not a single compound form in the two hours of NE speech analyzed. Reasons for this finding are dealt with later in this section, after we treat the related question of morphological aspectual marking.

Similar to the plight of compound tenses discussed above, aspect fails to be marked in NE, despite its use by L2E speakers. SE expresses event structure using aspectual affixes: $e k$ - 'punctual, ingressive', -igi 'ingressive', -ad- 'continuous', re- 'iterative', and $e l$ - 'telic' (4).
(4a) plori 'to cry'
(4b) ekplori 'to cry (punct.) / to start to cry'
(4c) plorigi 'to start to cry'
(4d) ploradi 'to keep crying'
(4e) replori 'to cry again'
(4f) elplori 'to cry [telic]'

Of these, only $e k$ - (in ekploris 'started to cry') is attested in NE, in only one token uttered by the Swiss-German-speaking child. That Swiss-German has aspectual verbal prefixes is perhaps significant, but by no means is it a sufficient condition for the presence of aspectual verbal prefixes. Russian and Slovak saliently share this characteristic as well, and yet the Slavic bilingual children found no use at all 
for aspectual prefixes. On the contrary, in the L2E corpus, there were 33 uses of verbal affixes (-ek (1), -igi (9), re- (10), and el- (12)), and in 15 minutes of the French mother's speech there were four (igi (2) and el- (2)) (Table 2).

< Insert Table 2 about here >

The reduction we have observed in NE is startling both because is seems to contradict bioprogram and other universalist predictions about the structure of a language learned in abnormal circumstances (Bickerton 1985), and because the loss of aspectual morphology in combination with the loss of complex tense structure described above leaves the grammatically expressible event structure of NE apparently rather meager, compared to SE and L2E.

To account for the disappearance of these forms, we might forward two hypotheses. Either (a) they are unnecessary for the communicative needs of the speakers who do not use them, specifically, following Slobin (1977), the semantics they express is superfluous, or (b) speakers express the range of concepts originally intended for these complex tenses using other linguistic tools, or (c) both. In other words, it might be that NE speakers do in fact overtly express progressivity and other aspectual notions using word order, subordination, aspectual adverbs, or by some other means. If this is not the case, we will be forced to posit that they rely on verbs' inherent aspectual semantics and on the discourse context.

In the NE corpus, there are no correspondences between constituent order or subordination and aspect, but some temporal adverbs do crop up, as does very limited verb serialization, which may take 
up some of the aspectual slack left by the loss of aspectual morphology and compound tenses. There is one case in the NE corpus of each komensi 'start' or fini 'finish' + Verb (5).

(5a) Kaj poste si finis polvosuci. (Swiss-German, age 9)

And then she finishes vacuuming.

(5b) Knabo komensis plori. (Slovak, age 11)

[The] boy starts to cry.

There are also four cases of ankorâ 'still' used as a verbal modifier (e.g. (6a)), dozens of cases of

(kaj) poste '(and) then' to string events together (6b), and one case of subordination (6c).

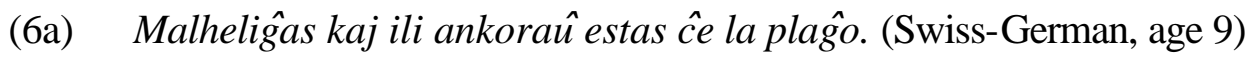

It's becoming dark and they are still on the beach.

(6b) Li forkuris kaj posta li ploris. (Slovak, age 9)

He ran away and then he cried.

(6c) Poste, do ke la patrino finis kun tio kio nomas gin... (Hebrew, age 13)

After, then, that the mother finished with the whatever it's called, ...

These means for expressing Event Structure are not nearly as uniformly used by NE speakers as their SE equivalents, nor are they used as commonly. Thus the answer to the above query seems to be a combination of the two solutions: other means are found for expressing some aspectual notions, but 
they are not nearly as common as in the children's adstrates, which obligatorily express aspect, even when it is more redundant than a native speaker of Esperanto might think necessary.

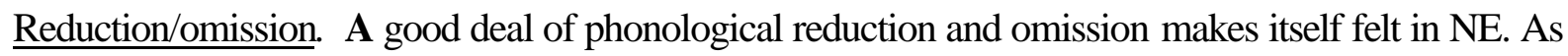
might be expected, the most frequently reduced forms are among the most frequently occurring, including - $o$ 'NOM', - $i$ 'PRON', la 'the', monosyllabic adverbs and prepositions, and -as 'PRES')

Nominative personal pronouns in Esperanto all end in /i/ (Table 3), and the vowel of these forms is the most commonly reduced segment in the language. The realizations of these reduced pronouns range from the simple reduction of the vowel to [ə] to elision of the whole lexeme. A total of 20 forms were reduced, around $5 \%$ of all nominative pronouns produced (Table 4). This reduction, while not constituting in and of itself the entire pronominal cliticization process, is nonetheless a step in the direction that many languages, especially creoles, have taken (DeGraff 1993; Veenstra 1996).

\section{< Insert Table 3 about here >}

The definite article la was reduced a total of 17 times, most frequently by the Russian (B) and Slovak (G and I) speakers. (Neither Russian nor Slovak has a definite article.) Similarly, the -o suffix which marks all nouns was omitted 13 times, although this process is present in SE as well, especially in compound words and before vowel-initial words. ${ }^{3}$ Finally, monosyllabic words like al 'to' and je 'at', which in Esperanto can only belong to the grammatical categories of prepositions or adverbs, were reduced a total of 12 times. 


\section{< Insert Table 4 about here >}

Sankoff \& Laberge (1973) discuss a similar phenomenon in Tok Pisin, where the pidgin form baimbai 'soon' has progressively eroded to bai and then bə. They relate this trend to the different speeds with which native and non-native speakers produce their language. Even though parents might be fluent speakers of a pidgin (or in the present case, Esperanto), the fact that they do not speak it natively slows speech production: 'The children speak with much greater speed and fluency, involving a number of morphophonemic reductions as well as reduction in the number of syllables characteristically receiving primary stress' (p. 35). Slobin (1977) argues to the same effect that reduction of (especially common) words relates to language's need to be 'quick and easy', and proceeds to relate the creolization case to historical linguistic developments and language contact situations.

All of the reductions found in NE occur on unstressed syllables (all SE words have penultimate stress), many of which are final. This seems to partially confirm Leskien's (1907) claim that Esperanto final syllables are subject to merger. However, contrary to Leskien's suggestions, this reduction does not lead to the degeneration of the functionality of the language; rather, it is a step in the language's evolution that does not seem to hinder communicative ease; it may even help, given Slobin's maxim of optimizing brevity/conciseness.

Discourse structure at the sentential level. SE has no prescribed sentential constituent order, which, whether Zamenhof intended it or not, allows the full range of word-order typologies of the world's languages to be expressed in Esperanto. However, most L2E is SVO, as is NE. 
For L2E, Sherwood (1982) found that around 93\% of the transitive clauses uttered by four L2E speakers (native speakers of English, Polish, Bulgarian, and Flemish) were (S)VO. Our French mother (K) uttered only two non-SVO transitive clauses. As for NE, only eight non-SVO transitive clauses were produced (all OSV), of which four belonged to the Swiss German child (e.g. 7). Some of these can be argued to derive from adstrate influence: Swiss German allows preposing of the direct object for focus. The difference between L2E and NE on this parameter is not significant.

(7) $\quad \mathrm{Cu} \quad$ tio[n] ankaû klarigu?

INTER this also clarify Clarify this one too?

Of particular interest to the 'Esperanto as creole' question is the prediction that if NE were behaving as a creole, its sentences should tend to be topic-comment structured (Li 1976; Escure 1997). Interestingly, the topic-comment construction does not occur in the NE corpus. Although this is not direct evidence against its use, we might expect it to surface at least once if it were an integral aspect of NE. It appears, from the data surveyed here, not to be.

The accusative. Perhaps the longest disputed feature of Esperanto is its accusative case. Analyses of Esperanto typically describe a total of three cases: nominative, prepositional, and accusative, where the nominative (8a) is unmarked, the prepositional (8b) marked by a preposition and no nominal or adjectival morphology, and the accusative marked with the suffix $-n$ on direct object nouns and adjectives (8c) and on adverbial complements expressing 'motion towards' (8d). 
(8a) La granda knabo estas en via cambro.

The big boy is in your room.

(8b) Mi donos gin al la granda knabo.

I will give it to the big boy.

(8c) Mi piedbatis la grandan knabon.

I kicked the big boy.

(8d) Mi iros hejmen.

I will go home.

The retention in Esperanto of the accusative is extremely controversial. As early as 1895, following much discussion about the accusative's utility and its learnability, Zamenhof put the decision up to a vote to retain it or not (Zamenhof 1929). The Esperantists of the day decided in favor of maintaining it, but fifteen years later, the accusative, among other features of Esperanto, led to a separatist movement that would result in the daughter language Ido (Couturat 1910).

Proponents of reform have advocated the elimination of the accusative case, which would leave no case morphology at all on nouns and adjectives. Others oppose such steps on the grounds that maintaining accusative marking allows (relatively) free word order, thus creating increased internationality and range of expression. Essential to this retentionist argument is the claim that the accusative is actually used as a mechanism for encoding distinctions, and is not simply redundant. In other words, the sentences in (9a) and (9b) should be used regularly as distinctive. That is, we should 
not find word order to correlate regularly with case, such as in alternations like the one between (9a) and $(9 \mathrm{c})$.

(9a) La knabino pusis la hundon.

The girl pushed the dog.

(9b) La knabinon pusis la hundo.

The dog pushed the girl.

(9c) La hundo pusis la knabinon.

The dog pushed the girl.

However, as seen above, there is very little variance from SVO order in NE. We should therefore not be surprised if the accusative plays a less vital distinctive role than it has been claimed by opponents of its elimination to be.

Whether or not it is redundant, recent studies show that the accusative is in use in L2E more or less as prescribed in SE (Sherwood 1982). Specifically, Sherwood's (1982) corpus contains only six accusative 'errors' in thirty minutes and the French parent (subject $\mathrm{K}$ in Table 5, below) made only two accusative errors in fifteen minutes. Versteegh (1993) specifically predicts little change between the L2E and NE uses of the accusative. We will see in this section that, in contrast with L2E, there is a cline of loss of the accusative in NE, ranging from minimal (inattention-based) omissions through sporadic application and use with pronouns only, to the loss of all productive use of the accusative, with it remaining only in idioms. This trend speaks strongly to the redundancy and superfluousness of the accusative. 
In total, as Table 5 shows, the accusative is used in around half of its prescribed SE environments in NE. The fourth column from the left, labelled ' $\%$ used', showing the percent use of the accusative relative to the environments predicted in SE, is the most important for our purposes.

< Insert Table 5 about here >

It is immediately clear that there is a correlation between the use of the accusative and the nature of case marking of the adstrate language. Precisely what we can conclude about this relation is discussed below. For the time being, though, suffice it to say that speakers of adstrates with the accusative are more likely to correctly use (as well as to overapply) the accusative, although this is far from a deterministic characterization. For example, while the Slovak (G and I) and Russian (B) speakers use the accusative most closely mirroring SE (at 97\%, 97\%, and 79\% respectively), the French speaker (H) and the Hebrew speakers (C and D) are the least standard (with accuracy rates of $0 \%, 56 \%$, and 6\%, respectively). ${ }^{4}$

More interesting, though, is to look at the details of the individuals' use of the accusative. Starting with the least SE-like use, the French speaker $(\mathrm{H})$ uses the accusative only idiomatically, specifically in the word saluton 'hello', and nowhere else. In fact, all speakers have at least this conventionalized use, although the extent to which the $-n$ of this form corresponds to the accusative elsewhere in their grammar has not yet been demonstrated.

The next least likely subject to use the accusative is the younger Hebrew speaker (D), who applies it (aside from saluton) only to the very common expression [li] satas tion '[he] likes that' (10a), but not elsewhere (10b, c), even with other pronouns (10d). 
(10a) Kaj la knabo ne satas tion.

And the boy doesn't like that.

(10b) Kaj la knabo prenas la simio. [SE: simion]

And the boy takes the monkey.

(10c) Kaj ci tie li fermas la sako. [SE: sakon]

And here he closes the bag.

(10d) Kaj la patro karesas li. [SE: lin]

And here the father caresses him.

Contrarily, the Croatian speaker (E) does make the leap to pronouns, but only definite pronouns immediately following the verb. Thus, the contrast between (11a) and (11b) arises.

(11a) Poste li iris kaj poste li prenis en unu mano lia simio. [SE: lian simion]

Then he went and then he took his monkey in one hand.

(11b) En la sepa, unu infano prenis lian strumpo. [SE: lian strumpon]

At seven o'clock, a child gets his sock.

The Swiss German speaker (A) displays the same behavior as the Croatian speaker (E), adding the accusative suffix to most direct object pronominal forms, except for the indefinite kio 'what', as shown in (12b). Unlike the Croatian speaker, however, this subject also extends the accusative to direct object nouns following possessive pronouns, as in (12a), but not to other nouns. 
(12a) Kaj la knabo fermas siajn [SE liajn] orelojn.

And the boy closes his ears.

(12b) Mi ne plu scias kio. [SE kion]

I don't know what anymore.

Continuing down the line, the older Hebrew speaker (C) makes greater use of the accusative, but shows definite signs of using it unnaturally or effortfully. For example, she does not use the accusative when responding to or continuing a sentence after an interruption, or with the verb havi 'to have', as seen in (14). In other environments, she applies it sporadically, shown in (13). On further analysis, however, many of her failures to apply the accusative in Esperanto can be described as adstrate effects: Hebrew does not use the same accusative marking for pronouns as for other NPs, which would give us the situation in (13a), and possession in Hebrew is expressed by placing the NP indicating the possessio in the nominative case, as in (14).

(13a) Mi satas ili. [SE ilin]

I like them

(13b) Ne, mi ne satas tion.

No, I don't like that.

(14a) Li havas bela nazo... [SE belan nazon]

He has a beautiful nose... 
(14b) Mi havas kato. [SE katon]

I have a cat.

Finally, the Russian (B) and Slovak (G and I) speakers show some minor 'mistakes', due most likely to inattention (or conversely, concentration on the task they were asked to perform). The overapplication of the accusative to prepositional contexts by these subjects will be discussed below.

Thus, we have seen that the accusative can be: (1) retained fully; (2) used sporadically; (3) kept only on pronouns; (4) kept only with pronouns directly following the verb; or (5) lost entirely, except for idiomatic usage. These results certainly do not paint the picture of a case distinction which is essential for effective communication. Very much to the contrary, there seems to be retention of the accusative only where the NE speaker's adstrate dictates such retention. And even in these cases, it is not used consistently.

Lexical stress. SE prescribes penultimate lexical stress for every polysyllabic word with the sole exception of nouns whose - $o$ suffix is (optionally) elided for phonotactic or prosodic reasons. Stress falls, in those words, on the final syllable instead (the 'underlying' penultimate syllable), giving variation like that in (15). This rule holds in SE even for proper nouns.

(15) La béla úrbo París(o) The beautiful city, Paris 
A preliminary (non-instrumental) investigation of the NE corpus produces the following results: (1) proper nouns are usually not given Esperanto phonology, including stress; and (2) there is a great deal of variation, even in Esperanto vocabulary, as to the location of lexical stress, particularly in 3+ syllable words.

The assimilation by Esperanto of 'international' words from natural languages (i.e. words that are already used internationally with similar forms, like telefono) includes proper nouns, as the example in (15) shows. In theory, these nouns are granted Esperanto morphology, giving Pariso, Benjamino Franklino, and so on. In NE, however, it turns out that not only do proper nouns often refuse the -o suffix, but they also often have extremely aberrant stress patterns (16). Since few proper nouns were available in the NE speech, quantitative measures are innapropriate.

(16a) Sólothúrn (Swiss city) (Swiss-German, age 9)

(16b) Mája (First name) (Russian, age 14)

(16c) Amériko 'America' (Hebrew, age 13)

(16d) Hájfa (Israeli city) (Hebrew, age 13)

(16e) Briançón (French city) (French, age 6)

Although NE generally exhibits penultimate stress, there is variation, especially in trisyllabic and longer words, as seen for the Swiss German speaker in (17)

(17a) nómîas 'is called'

(17b) ámikoj 'friends' 
(17c) denáske 'natively'

(17d) málgrándaj 'small (pl.)'

(17e) móntrofíngro 'index finger'

This apparent conflation of the prosodic structures of the two languages in which the child is native is not at all surprising, especially when it comes to proper nouns, which might be expected to be phonologically aberrant in a given language, anyway.

\section{DISCUSSION}

In this section, we will address the motivations for the various NE particularities described above, the extent to which the Esperanto nativization situation resembles creolization, and some theoretical ramifications of the phenomena presented above.

Where change comes from. Our method for identifying the effects of adstrate interference deriving from bilingualism, those of parental L1 interference on L2, and what must be described as nativization effects will proceed as follows. We will first assess the correlation between L2E - NE differences and adstrate characteristics (e.g. if speaking an adstrate without the accusative makes it more likely for a NE speaker to disregard the accusative). We will then make special reference to the one child-parent pair for which we have evidence to examine the extent to which adstrate influences on the parent's speech are internalized by the child. 
The reduced tense/aspect system of NE described above is consistent across speakers, just as L2E speakers seem to consistently have a much fuller system. Since all of the adstrate languages spoken by the NE speakers (and their parents) have either Indo-European compound verbal forms or aspectual verbal morphology or both, we can provisionally conclude that the loss of tense/aspect marking must derive from some other impetus. Precisely what this source is lies beyond the scope of the present paper, but some candidates might nonetheless be forwarded: facts about children's speech (all of the speakers in the NE corpus are younger than 15 and all the L2E speakers analyzed adults); differences between registers of the parents' speech (less formal, domestic speech using less frequent or less regular tense/aspect marking); or possibly some facts about nativization, e.g. desire to regularize forms that are used irregularly in the parent. Unfortunately, for this case, the French mother/daughter pair does not give us conclusive evidence, since the mother uses only one compound form and four aspectual affixes. It may be that due to the rather formal nature of the interview situation (with a tape recorder and linguist in front of her), she used a more formal register than at home, or perhaps she spoke exactly as at home. $^{5}$

The case of reduction is less clear since it can have very different causes, ranging from the omission of the lexical item entirely to a reduction of unstressed vowels. It is also more complex than the tense/aspect case because there is wide variation in its realization. Aside from some correlations between reduction patterns and adstrate characteristics, such as Slovak and Russian speakers eliminating the definite article more than any other speakers, there is little agreement between the characteristics of speakers of the same adstrate (who are siblings). It is not possible to say for the adstrate influence cases whether they are innovations of the NE speakers or their parents. However, 
since no reduction at all was observed in the French mother, while a great deal was produced by her child, we can assume that at least some of the reduction must be child-driven. ${ }^{6}$

As mentioned briefly above, there is a tendency for the accusative to be used more by NE speakers who speak an adstrate which overtly marks the accusative. However, because of the Swiss-German and Croatian speakers, both of whose adstrates mark the accusative, but who use it infrequently in Esperanto, we must reconsider the nature of the Esperanto-adstrate interaction. Evidently, some more general motive is pushing NE speakers not to use the accusative, and the fact of having an adstrate with the accusative retards this effect. Although we cannot say with certainty that parents speaking native languages with the accusative use it perfectly in Esperanto, we can warrant the guess on the basis of the L2E results covered above that they probably use it relatively consistently, placing the responsibility for the loss of the accusative on the shoulders of the child. Further evidence that parental deficiency is not necessarily at the heart of the change comes from the French situation, where, although the mother uses the accusative with extreme ease and accuracy (97\%), the child does not use it productively at all.

We can conclude that certain effects result from the influence of an adstrate. One of these, the loss of the accusative, is affected by the speaker's adstrate, and to a very large extent, this effect must take place at the level of the child, rather than the parent. By contrast, the loss of the tense/aspect system is most likely due to a more adstrate-independent motivation.

The Creole Conundrum. The learning situation in which NE is acquired in not the canonical one. Rather, NE is learned in an artificially created language contact situation (Thomason \& Kaufman 1988), in which multiple languages are used for multiple purposes, and where one of the languages is the native 
language of only the child. In this section we will comment briefly on where in the language contact spectrum NE acquisition seems to fit, based on the evidence presented above.

It seems from the fact that the greater part of NE speakers have parents of the same linguistic background (Corsetti 1996), thus not leading to the use of Esperanto as an emergency code, as well as from evidence presented above, that L2E speakers tend in fact to be quite proficient and that the Esperanto of parents is not very much like a pidgin language.

On the other hand, the linguistic input to children learning NE will in fact be L2 input, which inevitably leads to nativization effects. It should be noted that Esperanto nativization differs from the kind of community nativization normally discussed in the literature (e.g. Arends and Bruyn 1994), since in the Esperanto case there is only an extremely sparse linguistic community. Rather, nativization of Esperanto happens at the familial level. Although there are many organizations of Esperanto speaking families, the great majority of NE speakers do not participate in these groups, and even if they do, they usually do not spend more than a week or so with Esperantophones outside their family in a year.

These nativization effects take the forms described above: they can come form native language influence on the parents' Esperanto, adstrate influence on the child's learning of Esperanto, or from other, universal or acquisition-processual factors. As a first-generation native language, modified from the form of the language spoken by the speaker's parent(s), NE could felicitously be described as a creoloid: a language with creole-like properties that is nevertheless not a full creole (Sebba 1997).

Theoretical Ramifications. In the present section, we will see some theoretical ramifications for the findings described above on the reduction of the tense-aspect system, the attrition of the accusative, and the fixing of SVO word order. 
As shown above, the simple present, future, past, and progressive forms are the most frequently used in NE, while compound tenses, as well as the conditional, and other aspectual markings seem to have been left by the wayside.

Derek Bickerton (1985) has suggested that in cases of language acquisition where the adult model of the language does not provide children with a langage model from which they can derive general and systematic rules, those children rely on an 'innate bioprogram' to construct their native language. He suggests that this innate device is responsible for providing the child with 'a single and fairly specific grammatical model' (1985:147), which is reflected in the world's creole languages. The most strongly touted characteristic of this innate device is the conjugation of the verb, which takes the form depicted in Table 6 below in many creoles (based on a figure from Bickerton (1985)). Slobin (1977) on the other hand sees the tendency for languages to minimally develop these kinds of semantic markings as derivative of their need to be semantically expressive.

\section{$<$ Insert Table 6 about here >}

Whichever explanation we prefer, NE seems to differ from SE in part by selecting to retain only a subset of the 'universal' temporal/aspectual markings in Table 6. In looking closely at the attested NE forms in Table 7, we notice that the 'nonpunctual' and 'anterior + irreal forms' do not appear in NE (marked with a '-?'). This suggests that universalist or functional reasons why these markers must appear in every language, including those acquired in non-canonical language-learning contexts, are based on a false assumption. 


\section{< Insert Table 7 about here >}

The evidence presented above of children's ability to communicate natively in Esperanto without the accusative (and their corresponding selection of consistent SVO word order) adds to Sherwood's (1982) conclusion that the accusative is superficial and retained more for psycho-social reasons that for linguistic ones. We will now turn, however, to the patterns of the accusative's retention. There are certain semantic trends in the application of the accusative that we have uncovered in NE which are also found in other natural languages, and we are now at a point where we might wish to investigate the extent to which they provide insight into the behavior of the accusative in general.

In looking closely at the cases described above, there seems to be an implicational hierarchy of the retention of the accusative. This hierarchy, possession/impersonals > personal pronouns/definite NPs > idioms, is shown schematically in Table 8 . We certainly wouldn't want to make the strong claim that there is a universal (functional) mechanism that leads to this particular patterning of the distribution of possible accusative-marked objects simply on the basis of this data from Esperanto, since much of the above patterning can be chalked up to adstrate influence: Hebrew and Croatian do not mark impersonals or possessed objects with the accusative, Swiss-German has very little morphological distinction between the nominative and accusative, and French marks the accusative, like English, exclusively on pronouns.

< Insert Table 8 about here > 
This phenomenon is still of interest, whether the hierarchy in Table 8 reflects tendencies in the loss of the accusative when it is redundant, or simply tendencies in languages in general which happen to be exerting adstrate influence on NE.

CONCLUSION

In the preceding pages, we have presented the first systematic comparative analysis of Native Esperanto, and have outlined five divergences from Standard Esperanto: the attrition of the tense/aspect system and of the accusative, the fixing of SVO word order, the irregularity of lexical stress, and the tendency for phonological reduction, especially of pronouns and certain verbal morphology. Additionally, we have sought to explain each in terms of adstrate influence and general trends of language learning where the parents are not of the same native language as the language learners. Finally, we have discussed ramifications in the domains of the linguistic classification of Native Esperanto (as a creoloid) and innate and functional semantic universals.

We would like to mention as well that there is a wide range of linguistic phenomena not even touched on in the present study because they are present in many other languages and as such Esperanto has, at first glance, little to contribute to their study. However, that these phenomena, including consonant cluster reduction, focus-fronting, etc., are present in Esperanto provides further evidence for the value of studying Native Esperanto as a language, with special properties that can contribute to our understanding of language in general. 
In conclusion, let us for a moment reflect on the question of the future of Esperanto. What are the chances that the characteristics of $\mathrm{NE}$ described in the present study will be incorporated into the language as spoken by the Esperantophone mainstream? For example, if these NE speakers became parents, could this conceivably lead to the loss of the accusative in the following generation? This situation is unlikely, as most Esperantists are not native, and most native Esperantophones are not active Esperantists (Forster 1982). But were NE to become the norm taught to children, we would expect the accusative to disappear, as well as for dialects to emerge, as there would be extreme variation in its use. In other words, it would behave as naturally as any other native language, artifical or not. 
REFERENCES

Arends, J. \& A. Bruyn (1994). Gradualist and Developmentalist Hypotheses. In J. Arends et al. (eds.), Pidgins and Creoles: An Introduction. Amsterdam: John Benjamins.

Auld, W. (ed.) (1984). Esperanta antologio: Poemoj 1887-1981. Rotterdam: Universala Esperanto Associo.

Balbin, J. (1987). Is Esperanto a Romance Language? In J. Levitt, L. Ashley, K. Rogers (eds.), Geolinguistic Perpectives. Lanham, MD: University Press of America.

Bickerton, D. (1985). Creole Languages. In V. Clark, P. Escholhz, \& A. Rosa (eds.), Language: Introductory Readings. New York: St. Martin's Press.

Boulton, M. (1960). Zamenhof, Creator of Esperanto. Routledge and Kegan Paul: London.

Butler, M. C. (1921). Infana Esperanto. Literaturo 12, October-December 1921.

Corsetti, R. (1994). Andrea diras "ti-ta." Disaj observaj pri la kreoliĝo de Esperanto. Esperanto 87:4, 63-64.

Corsetti, R. (1996). A Mother Tongue Spoken Mainly by Fathers. Language Problems and Language Planning 20:3, 263-273.

Couturat, L. (1910). On the Application of Logic to the Problem of an International Language. In L. O. Couturat et al. (eds.), International Language and Science. Constable \& Company Limited: London.

DeGraff, M. (1993). Is Haitian Creole a Pro-Drop Language? In F. Byrne \& J. Holm (eds.) Atlantic Meets Pacific. Amsterdam: John Benjamins. 
Duc Goninaz, M. (1974). Les influences slaves en Espéranto. Cahiers de linguistique, d'orientalisme, et de slavistique 3-4, 31-53. Université de Provence.

Escure, G. (1997). Creole and Dialect Continua. Amsterdam: John Benjamins.

Forster, P. (1982). The Esperanto Movement. New York: Mouton.

Hockett, C. F. (1958). A Course in Modern Linguistics. MacMillan Co.

Janton, P. (1993). Esperanto: Language Literature, and Community. H. Tonkin (ed.). Albany: State University of New York Press.

Kalocsay K. \& G. Waringhien (1985). Plena Analiza gramatiko de Esperanto. Rotterdam: Universala Esperanto-Asocio.

Leskien, A. (1907). Zur Kritik des Esperanto. In K. Brugmann \& A. Leskien (eds.), Zur Kritik der künstlichen Weltsprachen. Straßburg: Karl J. Trübner.

Li, C. (ed.) (1976). Subject and Topic. New York: Academic Press.

Mühlhäuser, P. (1980). Structural Expansion and the Process of Creolization. In A. Valdman \& A. Michfield (eds.), Theoretical Orientations in Creole Studies. New York: Academic Press.

Pei, M. (1958). One Language for the World. New York: The Devin-Adair Company.

Piron, C. (1984). Contribution à l'étude des apports du yidiche à l'Espéranto. Jewish Language Review 4, 15-29.

Samarin, W. (1994). The Dynamics of Morphotactic Change in Sango. In K. Peterson \& C. Wentum (eds.), The Proceedings of the 20th Annual Meeting of the Berkeley Linguistics Society: Special Session on Historical Issues in African Linguistics. Berkeley: Berkeley Linguistics Society.

Sankoff, G. \& S. Laberge (1980). On the Acquisition of Native Speakers by a Language. In G. Sankoff (ed.), The Social Life of Language. Philadelphia: University of Pennsylvania Press. 
Sebba, M. (1997). Contact Languages: Pidgins and Creoles. New York: St. Martin's Press.

Sherwood, B. A. (1982). Statistical Analysis of Conversational Esperanto, with Discussion of the Accusative. Studies in the Linguistic Sciences 12, 165-182.

Slobin, D. (1977). Language Change in Childhood and in History. In J. MacNamara (ed.) Language Learning and Thought. New York: Academic Press.

Thomason, S. \& T. Kaufman (1988). Language Contact, Creolization, and Genetic Linguistics. Berkeley: University of California Press.

Veenstra, T. (1996). The Pronominal System of Saramaccan. In D. Véronique (ed.), Matériaux pour l'étude des classes grammaticales dans les langues créoles. Aix-en-Provence: Publications de l'Université de Provence.

Versteegh, K. (1993). Esperanto as a First Language: Language Acquisition with a Restricted Input. Linguistics $31,539-555$.

Zamenhof, L. L. (1929). Originala Verkaro, the collected original works of Lazar Ludvik Zamenhof, J. Dietterle (ed.). Leipzig: Ferdinand Hirt. 
TABLES

TABLE 1. Attested participles in L2E

\begin{tabular}{lll}
\hline & Present & Past \\
\hline Active & & exmodiginta 'starting to become out-moded' \\
Passive & konata 'known' & ordigita 'ordered' \\
& & trenita 'towed' \\
& solvita 'solved' \\
& tradukita 'translated' \\
& reeldonita 'republished' \\
& kunigita 'united' \\
& korektita 'corrected' \\
\hline
\end{tabular}


TABLE 2. Attested aspectual prefixes in L2E

\begin{tabular}{|c|c|c|c|c|}
\hline & $e k-$ & $-i \hat{g i}$ & re- & el- \\
\hline \multirow[t]{8}{*}{ L2E Corpus } & $\begin{array}{l}\text { ekscii 'to start to } \\
\text { know' }\end{array}$ & $\begin{array}{l}\text { perdigas 'start to } \\
\text { lose' }\end{array}$ & reagis 'reacted' & $\begin{array}{l}\text { elsercis 'searched } \\
\text { out' }\end{array}$ \\
\hline & & farigas 'start to go' & relegi 'to reread' & $\begin{array}{l}\text { eldonas 'gives out' } \\
\text { (2) }\end{array}$ \\
\hline & & $\begin{array}{l}\text { amikigas 'start to } \\
\text { be friendly' }\end{array}$ & reverki 'to rewrite' & $\begin{array}{l}\text { eldonos 'will give } \\
\text { out' }\end{array}$ \\
\hline & & $\begin{array}{l}\text { finigos 'will start to } \\
\text { finish' }\end{array}$ & revenas 'return' & $\begin{array}{l}\text { reeldonis 'reissued' } \\
\text { (2) }\end{array}$ \\
\hline & & $\begin{array}{l}\text { eksmodiginta } \\
\text { 'starting to be out- } \\
\text { moded' }\end{array}$ & $\begin{array}{l}\text { reeldonis 'reissued' } \\
\text { (2) }\end{array}$ & eldoni 'to give out' \\
\hline & & $\begin{array}{l}\text { farigus 'would start } \\
\text { to go' (2) }\end{array}$ & $\begin{array}{l}\text { respeguligas 're- } \\
\text { reflects' }\end{array}$ & eldonis 'gave out' \\
\hline & & $\begin{array}{l}\text { sentigas 'start to } \\
\text { feel' }\end{array}$ & reveni 'to return' & $\begin{array}{l}\text { reeldonu 'reissue } \\
\text { (imperative)' (2) }\end{array}$ \\
\hline & & $\begin{array}{l}\text { interestigas 'start } \\
\text { to be interested' }\end{array}$ & $\begin{array}{l}\text { reeldonu 'reissue } \\
\text { (imperative)' (2) }\end{array}$ & $\begin{array}{l}\text { eldonu 'give out } \\
\text { (imperative)' }\end{array}$ \\
\hline \multirow[t]{2}{*}{ French L2E } & & $\begin{array}{l}\text { plibonigi 'start to } \\
\text { improve' }\end{array}$ & & elmetis 'gave out' \\
\hline & & & & elteni 'hold out' \\
\hline
\end{tabular}


TABLE 3. Esperanto nominative personal pronouns

\begin{tabular}{|c|c|c|}
\hline Person & Singular & Plural \\
\hline 1 & $m i$ 'I' & $n i$ 'we' \\
\hline 2 & & \\
\hline 3 & $l i$ 'he', si 'she', oni 'one' & ili 'they' \\
\hline
\end{tabular}


TABLE 4. Attested reductions (total number of instances) in NE corpus

\begin{tabular}{cccccccccc}
\hline Subject & $-a$ & $-o$ & $-e$ & $-i$ & $-a s$ & $l a$ & 1-syll & Other & Adstrate \\
\hline A & 1 & 3 & 2 & 4 & 3 & & & & Sw. Ge \\
B & 1 & 3 & & & & 3 & 1 & 1 & Russian \\
C & & 5 & & 11 & 3 & 1 & 3 & 5 & Hebrew \\
D & 1 & & & 3 & & 1 & 5 & & Hebrew \\
E & & & & 1 & 1 & 1 & & 3 & Croatian \\
G & & & & 1 & & 7 & 1 & & Slovak \\
H & & 2 & & & 6 & & 2 & 4 & French \\
I & 1 & & & & & 4 & & 1 & Slovak \\
Total & $\mathbf{4}$ & $\mathbf{1 3}$ & $\mathbf{2}$ & $\mathbf{2 0}$ & $\mathbf{1 3}$ & $\mathbf{1 7}$ & $\mathbf{1 2}$ & $\mathbf{1 3}$ & \\
\hline
\end{tabular}


TABLE 5. Attested accusative use in NE

\begin{tabular}{lccccc}
\hline & Instances & Opportunities & \% Used & Overuses & Adstrate \\
\hline $\mathrm{A}$ & 7 & 36 & 19 & & Sw. German \\
$\mathrm{B}$ & 11 & 14 & 79 & 1 & Russian \\
$\mathrm{C}$ & 14 & 25 & 56 & & Hebrew \\
$\mathrm{D}$ & 1 & 18 & 06 & & Hebrew \\
$\mathrm{E}$ & 3 & 26 & 12 & & Croatian \\
$\mathrm{G}$ & 29 & 30 & 97 & & Slovak \\
$\mathrm{H}$ & 0 & 12 & 00 & & French \\
$\mathrm{I}$ & 31 & 32 & 97 & 2 & Slovak \\
TOTAL & $\mathbf{9 6}$ & $\mathbf{1 9 3}$ & $\mathbf{5 0}$ & $\mathbf{3}$ & \\
& & & & & French \\
\hline
\end{tabular}


TABLE 6. Bickerton's creole verb forms

\begin{tabular}{ccc}
\hline Verb form & Nonstative verbs & Stative verbs \\
\hline base form & 'He walked' & 'He loves' \\
Anterior & 'He had walked' & 'He had loved' \\
Irreal & 'He will/would walk' & 'He will/would love' \\
Nonpunctual & 'He is/was walking' & \\
anterior + irreal & 'He would have walked' & 'He would have loved' \\
\hline
\end{tabular}


TABLE 7. NE verb forms

\begin{tabular}{lll}
\hline Verb form & Nonstative verbs & Stative verbs \\
\hline base form & Piediri & ami \\
anterior & Piediris & amis \\
irreal & Piediros & amos \\
nonpunctual & - ?estas piediranta & - estas amanta \\
anterior + irreal & - estis piedironta & - ?estis amonta \\
\hline
\end{tabular}


TABLE 8. NE accusative implicational hierarchy

\begin{tabular}{lcccc}
\hline & Idiom & Definite NP & $\begin{array}{c}\text { Personal } \\
\text { Pronouns }\end{array}$ & $\begin{array}{c}\text { Possession/ } \\
\text { Impersonals }\end{array}$ \\
\hline $\mathrm{H}$ & $\mathrm{X}$ & & & \\
$\mathrm{A}$ & $\mathrm{X}$ & & $\mathrm{X}$ & \\
$\mathrm{D}$ & $\mathrm{X}$ & $\mathrm{X}$ & & \\
$\mathrm{C}$ & $\mathrm{X}$ & $\mathrm{X}$ & $\mathrm{X}$ & \\
$\mathrm{E}$ & $\mathrm{X}$ & $\mathrm{X}$ & $\mathrm{X}$ & \\
$\mathrm{B}$ & $\mathrm{X}$ & $\mathrm{X}$ & $\mathrm{X}$ & $\mathrm{X}$ \\
$\mathrm{G}$ & $\mathrm{X}$ & $\mathrm{X}$ & $\mathrm{X}$ & $\mathrm{X}$ \\
$\mathrm{I}$ & $\mathrm{X}$ & $\mathrm{X}$ & $\mathrm{X}$ & $\mathrm{X}$ \\
\hline
\end{tabular}


${ }^{1}$ One anonymous reviewer correctly points out that this analogy has its limits; (1) the L2 input to L1 Modern Hebrew learners was varied and idiosyncratic compared to L2 Esperanto, and (2) L2 Hebrew started out as a phonologically and morphologically complex and opaque system while L2 Esperanto is extremely regular and transparent.

${ }^{2}$ Indeed, there exist other composed forms that are even less typologically common, like the conditional participle, which are no longer even discussed except parenthetically in grammars, like Kalocsay \& Waringhien (1985:132).

${ }^{3}$ In fact, this is a well-recognized and endorsed feature of Esperanto poetry (cf. Auld 1984). ${ }^{4}$ Hebrew does have primary object marking et, which makes the non-use of the accusative by the younger Hebrew speaker that much more surprising.

${ }^{5}$ The fine-grained tense compounds could also be seen as rather "written" concepts, or just rather elaborated; perhaps the children restrict their use of Esperanto to basic kinds of expression and use the adstrate for subtler expression (John McWhorter, p.c.).

${ }^{6}$ For this we must assume that her level of reduction at home was not dramatically greater than when interviewed, which is possible, due to the phonology of French, which allows reduction of only a certain class of vowels. 